\title{
Secondary school students' perceptions of a mobile application design for smoking prevention
}

Rosa Dabinia Uribe-Madrigal', María del Carmen Gogeascoechea-Trejo², María de Lourdes Mota-Morales ${ }^{3}$, Christian Soledad Ortiz-Chacha ${ }^{3}$, Betzaida Salas-Garciá2 ${ }^{2}$ Enrique Romero-Pedraza ${ }^{4}$, María Cristina Ortiz-León ${ }^{3}$

\begin{abstract}
INTRODUCTION Our research was based on the BUS model, which provides guidelines for developing mobile applications for health. This model is supported by theories of behavior change, user-centered design, and social marketing. This study aimed to determine secondary school students' perceptions of a mobile application design for smoking prevention.

METHODS In 2018, qualitative research was conducted in three secondary schools located in the central part of the state of Veracruz, Mexico. Focus groups were established to explore beliefs about smoking and mobile phone use. The sketch technique was used to identify the characteristics for the mobile application.

RESULTS The students' perception of smoking allowed us to determine behaviors that can be changed: 1) associating cigarettes with a distraction from problems can be prevented; 2) peer and family pressure as a trigger to starting smoking can be avoided; and 3) tobacco use can be disassociated from being popular. Regarding the design of the mobile application prototype, an entertaining game with levels to help teenagers stay active was proposed.

CONCLUSIONS Games for health can help modify user behavior and even positively influence their values. The final product was the prototype for the 'No le entres' (don't jump in) application. An important finding was that adolescents living in both urban and rural settings use mobile phones similarly.
\end{abstract}

\section{AFFILIATION}

1 Public Health Institute, Master's in Public Health, University of Veracruz, Veracruz, Mexico

2 Health Sciences Institute, University of Veracruz, Veracruz, Mexico

3 Public Health Institute, University of Veracruz, Veracruz, Mexico

4 Psychological Research Institute, University of Veracruz, Veracruz, Mexico

\section{CORRESPONDENCE TO}

Maria Cristina Ortiz-León. Public Health Institute, Master's in Public Health, University of Veracruz, Av. Dr. Luis Castelazo Ayala s/n, Col. Industrial Animas, 91190 Xalapa-Enríquez, Veracruz, Mexico. E-mail: cortiz@uv.mx ORCID ID: https://orcid.org/0000-0003-4953-5076

\section{KEYWORDS}

prevention, tobacco control, educationyouth prevention, mobile application prototype

Received: 3 August 2020

Revised: 10 December 2020

Accepted: 31 January 2021

\section{INTRODUCTION}

In Mexico, 1.1 million active adolescent smokers have been reported to exist. Such a figure represents $7.8 \%$ of the population, where, according to the National Survey on Alcohol, Drugs and Tobacco Consumption ${ }^{1}$, the age of onset and daily consumption are 13.7 and 14.3 years, respectively. Therefore, further efforts are essential to prevent and reduce smoking in this age group, since by 2030 more than 8 million smokingrelated deaths per year are expected to occur ${ }^{2}$.

Engaging in healthy behaviors and easy access to quality information are the fundamentals of health promotion ${ }^{3}$. Engaging in healthy behavior is an individual decision; therefore, the individual behaviors of a given population group represent a behavior collective that has an impact on public health. Tobacco use is an unhealthy behavior, so individualized information, considering the characteristics of everyone such as age, sex, and type of consumption, among others, plays a key role when people choose whether to smoke or not. In this sense, Information and Communications Technologies (ICTs) have enhanced and even created new ways to perceive healthcare ${ }^{3}$. Within ICTs, mobile phones deliver a means of communication easily adaptable to these needs, since they are communication devices 
with a high rate of penetration for a large part of the population, particularly adolescents ${ }^{4}$.

Additionally, smartphones combine several features; they allow for communication, and many applications deliver immediate access to different content or entertainment ${ }^{5}$. The entry of these devices into people's daily lives can be exploited for their benefit. For example, developing applications gives rise to opportunities to promote health and make education more dynamic, interactive, and individual, and this can occur on a large scale, since the targeted population can be so easily reached. In addition, they are more profitable than other types of interventions ${ }^{6}$.

Article 12 of the Framework Convention for Tobacco Control establishes that available communication tools must be used to carry out interventions to prevent tobacco consumption. If we consider that adolescents are mobile phone users and make up a population where most users have access to mobile applications, then mobile phones could be used as a tool for smoking prevention in this age group ${ }^{7}$.

Digital objects, including mobile applications (apps), should be designed considering the specific needs of both the context and the community ${ }^{8}$. The BUS model considers these aspects. Its name is derived from three different concepts: B comes from Behavior Change Theories, U from User-Centered Design (UCD), and S from Social Marketing. BUS considers six stages: 1) situation analysis, 2) concept generation and prototype design, 3) prototype development, 4) pilot test, 5) launch campaign, and $6)$ assessment. In this model, it is critical that users are involved while the application is being designed in all stages, from the conceptual design to the final assessment. Behavior Change Theories and UCD are both used in all the stages, while Social Marketing only in five .

Regarding the Behavior Change Theories to develop interventions for adolescents, the following theories stand out: Health Belief Model ${ }^{10}$, the Theory of Reasoned Action ${ }^{11}$, and the Social Learning Theory ${ }^{12}$. Thus, we considered them when designing our app. The Health Belief Model predominated, which refers to the use of rewards for adherence to indications provided by health professionals to improve quality of life and prevent complications to their health state. The Theory of Reasoned Action points out that the influence of peers affects adolescent behavior. The Social Learning Theory stresses the importance of external influences on behavior since people learn by observing and learning about the experiences of others.

There is a history of UCD to study adolescents' perceptions of the features that smart applications should have with respect to health in the United States and Europe. We found that no studies like these have been conducted in the Latino or Spanishspeaking adolescent population. In most, the qualitative approach and focus groups to determine the characteristics necessary to design feasible and usable mobile applications for health predominate. Smoking cessation ${ }^{13}$, providing sexual education ${ }^{14}$, diabetes control ${ }^{15}$, asthma ${ }^{16,17}$, and increasing physical activity ${ }^{18}$ are some of the health problems to be solved. We found no studies on developing UCD-based applications for smoking prevention in adolescents.

When designing mobile apps, it is necessary to identify the target population and document the design process to determine the ideal features by considering their perspective as potential users to encourage their use. For the abovementioned reasons, this project aimed to determine secondary school students' perception of the characteristics of a mobile application for preventing tobacco use.

\section{METHODS}

\section{Study design}

We conducted a user-centered design qualitative approach $^{19}$. We implemented the first two phases of the BUS model: 1) situation analysis, and 2) concept generation and prototype design.

\section{Context}

We recruited students from three secondary schools located in the central part of the state of Veracruz, Mexico. Schools were identified as School 1, School 2, and School 3.

\section{Sampling strategy}

We selected the three schools and students by convenience. We included schools located in communities with different levels of marginalization and population centers. We included female and male 
public secondary school students in first, second, and third grade, aged 12-15 years. Students were both smokers and non-smokers, and all students were mobile application users.

\section{Data collection methods}

Two focus groups were held between October and November 2018 and another in February 2019. They consisted of three students per school grade, female and male, and both a moderator and a rapporteur took part. Before holding the focus groups, participants wrote their school grades and groups, sex, full name, and phone type (Android or iPhone) on the attendance list.

We used the same guide at the beginning of each focus group to standardize data collection, so we structured it as follows: a presentation to generate empathy among the participants and establish the rules for participation was shown. After this, the students received a brief introduction about health mobile applications, their purpose, and some examples. The next sections of the guide explored beliefs about tobacco use and mobile phone use in everyday life. To obtain the attributes, design, and contents of an app designed to prevent tobacco consumption, we used the sketch technique, where students were told to express themselves through drawings on white sheets with colored pencils. In the final part of the guide, we thanked participants for taking part in the sessions.

We reminded them that the information given in the group was exclusively for academic purposes and that it would be handled confidentially. We created an attendance list that included school grade, group, sex, age, and phone type. Since the participants were minors, informed consent forms were signed by the participants' parents. Students gave us their informed approval. This project was approved by the Technical Council of Instituto de Salud Pública (Public Health Institute), part of the University of Veracruz, which is empowered to issue both ethical and methodological opinions on research and is also the body empowered by the regulations with force in the university.

The sessions were recorded, with the consent of the participants, using a MacBook Air computer and a smartphone. RDUM and MCOL held the focus groups, as they have experience working with these groups.

\section{Processing and analyzing information}

We considered the following category analysis for data collected by the focus groups: 1) beliefs about tobacco use, with subcategories - health, family, friends, and status; 2) mobile phone use in everyday life, with the following usability subcategories - internet access, mobile applications, social networks, costs, rewards, and usage time; and 3) attributes of mobile applications, with the following subcategories - avatar, rewards, health behavior, color, type of application, and use of other elements.

BSG, MCGT and MLMM, which previously have done analysis, considered category analysis and manually transcribed and codified data collected by the focus groups. We then performed both a content analysis using segmentation and an iconic memory analysis to process visual information.

CSOC and MCOL, which have experience with qualitative research, verified transcribed data after codification was finished and if a segment matched the category analysis identified by at least two of the codifiers, then it was kept. Once identifying category analysis was analyzed and verified, results from the analysis were presented to the research team. ERP, RDUM and MCOL then selected eligible behaviors to be improved by developing a smart application, so they were able to generate the concepts that gave rise to our application.

After we generated the concepts, we then designed a low-fidelity prototype of our application to prevent smoking.

\section{RESULTS}

\section{Situation analysis}

\section{Relevant characteristics of participants}

School 3 is located in a rural town with a high level of marginalization, and internet access is limited. School 3 and School 2 were those with a greater number of participants (Table 1). In all the three groups, male participation predominated. In the focus groups of Schools 1 and 2 (Focus Groups 1 and 2, respectively), all participants had a mobile phone while the research was being conducted. In the focus group of School 3 (Focus Group 3), some participants had no mobile phones for unspecified family reasons. In all the three focus groups, Android-based mobile phones predominated, while in Focus Group 2 some students had IOS-based mobile phones. 
Table 1. Characteristics of both schools and participants taking part in the focus groups

$\begin{array}{lccc}\text { Characteristics } & \text { School } 1 & \text { School } 2 & \text { School } 3 \\ \text { Name of the town } & \text { Tlaltetela } & \text { Xalapa } & \text { Cantaranas } \\ \text { Type of town } & \text { Urban } & \text { Urban } & \text { Rural } \\ \text { Level of marginalization } & \text { High } & \text { Very low } & \text { High } \\ \text { Total number of students } & 267 & 1500 & 113 \\ \text { Participants per school } & 6 & 10 & 10 \\ \text { Sex } & & & \\ \text { Female } & 1 & 6 & 1 \\ \text { Male } & 5 & 4 & 9 \\ \text { School grade } & & & \\ \text { First } & 0 & 4 & 4 \\ \text { Second } & 2 & 6 & 2 \\ \text { Third } & 4 & 0 & 4 \\ \text { Type of mobile OS } & & & \\ \text { Android } & 6 & 7 & 5 \\ \text { IOS } & 0 & 3 & 0 \\ \text { Does not have one } & 0 & 0 & 5\end{array}$

Beliefs about tobacco use during the adolescent stage Secondary school participants knew about the health damage caused by tobacco use. They recognized that such a habit leads to death. A participant pointed out that:

'Smoking damages and contaminates your body, causing death.' (School 3, Male student)

They also identified substances contained in cigarettes that can affect their health. In turn, they stated that smoking not only damages the smoker, but also those around him or her.

'Mom taught me that smoking causes a lot of physical pain, like cirrhosis, and affects your liver. It is also bad for people living around you ... as tobacco smoke is in your clothes, you can make them sick and your lungs can get sick.' (School 2, Male student)

They have also heard or seen other people smoking, from which they had received positive messages about this habit, and they conceived this activity as pleasant, stress-relieving, and fun (because smoke comes out of your mouth). Some stated that flavored and colored cigarettes are an incentive to start smoking.

'When I smoke, I think of several flavored and colored cigarettes - those are not so strong.' (School 1, Male participant)

According to participants, their decision to start smoking is influenced by family. They emphasized that family problems affect them and cause them to smoke. They felt that, if a family member smokes, it is an invitation to experience and start smoking.

[Family] influences start smoking for several reasons. Problems at home is one of them and you try to find something to kill time or a family member smokes and he or she somehow convinces you, influences you or makes you try to smoke.' (School 2, Male participant)

However, some participants assigned their parents the role of counselors because they often give advice. Nevertheless, participants themselves stay away from counselling sessions and make decisions without taking them into account.

'Parents often give advice because they want to help you, but you don't listen, you don't give a $f .$. damn.' (School 3, Male participant)

They believe that friendship plays a key role in decision-making, particularly when starting to smoke. In the three schools, young smokers are visible and put pressure on others to start smoking. To do so, they use challenging phrases such as:

'You are a man, men smoke, are you a pussy or what?' (School 1, Male participant)

The belief that smoking brings popularity, importance and power stood out in the focus groups:

'Smoking makes you popular, the others see you as an older and a mature guy and you become important for them, they want to be like you, they start admiring you for an unknown reason.' (School 2, Female participant)

'You smoke because you want to imitate artists, singers, if they smoke and just do fine, why can't you?' (School 1, Male participant)

\section{Mobile phones in everyday life}

Mobile phones are used to play games, competition games as well as violent or war games. Participants from both urban and rural environments play the same games. They also use mobile phones to communicate 
with their friends through social networks or instant messaging services.

'I use my mobile phone for chatting or checking. Facebook and catching up with gossips about other classmates. I like playing either Free Fire or Fortnite because we can kill people.' (School 2, Female participant)

'I use more Facebook, Messenger and games like Free Fire or that one ... Fortnite, they are so cool. Besides, they have a lot of levels and their graphics are sof... cool.' (School 3, Male participant)

In addition, mobile phones are useful for them to keep themselves informed about sports as well as watch and download videos.

'I use my mobile phone for Messaging my friends and parents and watching and listening to musical videos. For watching porn. For playing Free Fire. It's so cool!' (School 3, Male participant)

In a single group, it was mentioned that mobile phones were used to do homework.

'I use it [the mobile phone] for doing homework or researching topics.' (School 1, Male participant)

We observed that social networks are part of the daily life of young people. Social networks have become essential for them, regardless of whether they come from communities with low or high levels of marginalization.

'I check Facebook and YouTube. I also play Fortnite or Free Fire, as you can meet people and chat with others.' (School 2, Male participant)

Figure 1. Sketches drawn by focus group participants

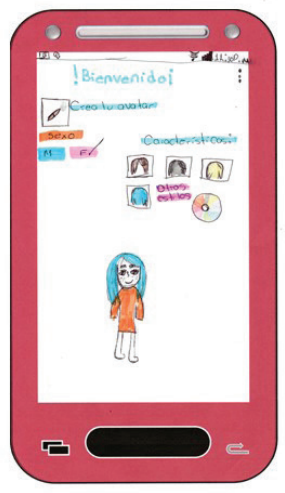

a) School 2-Female

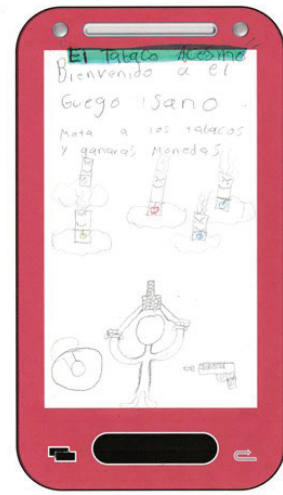

b) School 1-Male

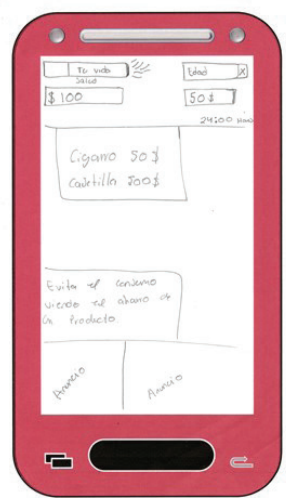

c) School 2-Male

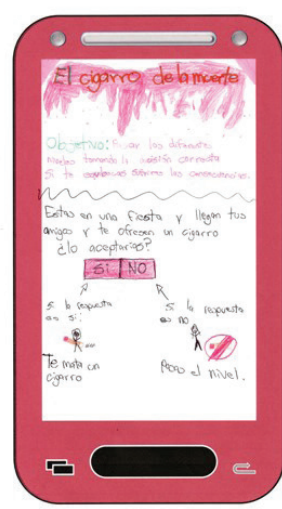

d) School 3-Female
Participants only download free apps that provide them with prizes or rewards to keep their interest.

'I like that games and apps are free, as I can download them. I prefer playing on $P C$, it is easier and free ... using the keyboard is pretty cool, as my mobile phone freezes and you can't play very well.' (School 2, Male participant)

We observed that they are constantly close to their phones so that they can spend more time on them. Participants living in rural environments spend fewer hours on their mobile phones because of the quality of the signal - not because of a lack of desire or interest.

'At school you are not allowed to check your phone in classes, but I am virtually checking my apps all day. Sometimes I only want to watch what time it is, when I realize I already have notifications about my apps and I stay hours looking at them ... all day I have an urge to be checking notifications.' (School 2, Female participant)

'Well, I spent about 4 hours checking my apps, because my Internet is unstable.' (School 3, Male participant)

\section{Attribute coding for app design}

According to participants' perception, designing an application to prevent tobacco use must be governed by an avatar (Figure 1a). Games must be developed, for example, to kill cigarettes, answer questions, and earn points to improve the appearance of the avatar (Figure 1b).

Regarding the prevention of tobacco use, they 
stated that it is important to be informed and aware of the risks of smoking by using audiovisual tools, which would reinforce their knowledge and provide motivational messages. They also pointed out that, at the end of each level of the game, they should be told how important it is not to start smoking. They said that it should be emphasized that not smoking is beneficial for their health and for maintaining a high quality of life and that they save money when they do not buy cigarettes (Figure 1c).

Use of vibrant and bright colors prevailed in the designs of the three groups. There was a preference to developing war-based games with weapons. However, there were variants where the user was a caregiver that prevented the person they are looking after from starting to smoke. They also said that a game to strengthen their thinking skills with questions to assess their knowledge and learning should be developed. Moreover, they also proposed a decision-making game where, if the player decides not to smoke, then the player can move on to the next level (Figure 1d).

Participants said that watching educational videos on YouTube was important for them to stay informed about tobacco risks (Figure 2a). A chat was also proposed whereby participants can meet other participants who have smoked and, through interaction, learn from their experience. They also stated that health professionals should be included so that participants can learn more about the consequences of tobacco use from an expert's perspective. Another interesting suggestion was to link the app with associations that fight tobacco use and addictions, and the money collected when playing the app should be given to these associations (Figure 2b). All groups proposed to link the app with other social networks such as Facebook, Instagram, and WhatsApp (Figure 2c), in addition to relying on games like Free Fire (Figure 2d).

\section{Concept generation and app design to smoking prevention}

With the information collected, we proceeded to target behaviors that could be feasibly modified by an app: 1. Regarding cigarettes as a distraction for participants' problems.

2. Being pressured from friends and family.

3. Regarding tobacco use as popular.

Table 2 shows the behaviors to be modified, the way to intervene, and the elements that can be easily incorporated into our app.

\section{Prototype design}

Our app prototype was called 'No le entres' (don't jump in), as a warning against starting smoking. Figure 3 shows the navigation map. It starts with application access through three social networking sites: Facebook, Twitter, and Gmail. After that, the privacy notice pops up and provides information about data protection. The next few lines briefly describe

Figure 2. Sketches drawn by focus group participants

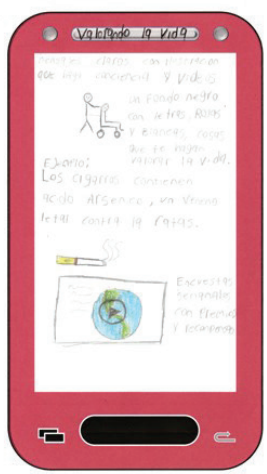

a) School 1-Male

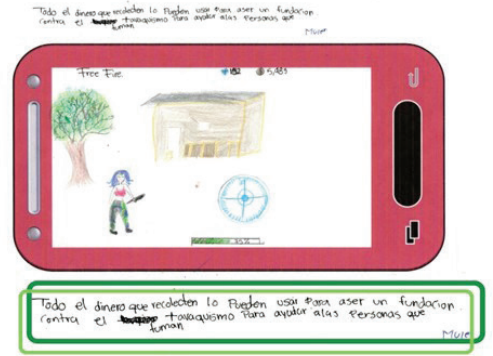

b) School 3-Female

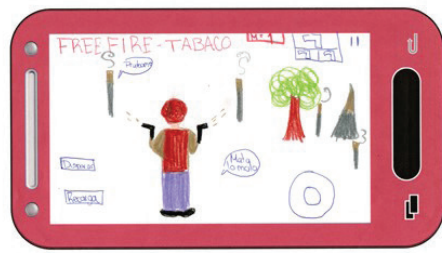

d) School 2-Male

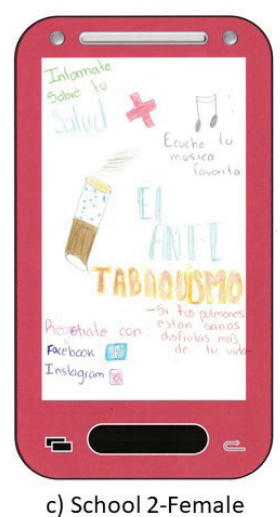

c) School 2-Female 
Table 2. List of behaviors to be changed, how to intervene and elements to be incorporated into our app

\begin{tabular}{|c|c|c|}
\hline Behaviors to be changed & How to intervene & Element to be incorporated into our app \\
\hline $\begin{array}{l}\text { - Prevent associating the } \\
\text { cigar as a distraction for } \\
\text { problems. }\end{array}$ & $\begin{array}{l}\text { - Leisure and entertaining } \\
\text { activities. }\end{array}$ & - A three-level game as a positive distraction to avoid tobacco use. \\
\hline $\begin{array}{l}\text { - Prevent pressure from } \\
\text { peers and family to start } \\
\text { smoking. }\end{array}$ & $\begin{array}{l}\text { - Strengthening the } \\
\text { autonomy of teenagers } \\
\text { with positive messages } \\
\text { and information on } \\
\text { the damage caused by } \\
\text { tobacco use during the } \\
\text { adolescent stage, so that } \\
\text { they can recognize harmful } \\
\text { behaviors. }\end{array}$ & $\begin{array}{l}\text { - Short videos with positive non-smoking messages, infographics, illustrations } \\
\text { and memes will contain 'Did you know that' ... information, supported by data } \\
\text { and statistics. According to the Theory of Reasoned Action that emphasizes } \\
\text { the influence of peers on behavior, YouTubers and influencers, who are popular } \\
\text { among teenagers, will be invited to participate in the short videos. }\end{array}$ \\
\hline $\begin{array}{l}\text { - Do not associate } \\
\text { tobacco use with being } \\
\text { popular. }\end{array}$ & $\begin{array}{l}\text { - Stimulating talents, skills } \\
\text { and interests to benefit } \\
\text { their health. Prevent } \\
\text { relating tobacco use with } \\
\text { acceptance to social groups } \\
\text { in their environment. }\end{array}$ & $\begin{array}{l}\text { - Answering questions. According to the Model of Health Beliefs, if answers } \\
\text { are correct, teenagers will receive rewards, either a gift coupon or accessories } \\
\text { for the avatar, in addition to moving on to the next level. } \\
\text { - A decision-making level, where teenagers will put into practice what they } \\
\text { have learned and choose between two situations (one that puts them at risk } \\
\text { and another that keeps them healthy). Thus, teenagers will reinforce their self- } \\
\text { esteem and confidence in themselves and avoid associating tobacco use with } \\
\text { the need to being accepted by the social groups around them and achieve a } \\
\text { popularity status. }\end{array}$ \\
\hline
\end{tabular}

Figure 3. Navigation map of ¡No le entres! (Don`t jump in) app

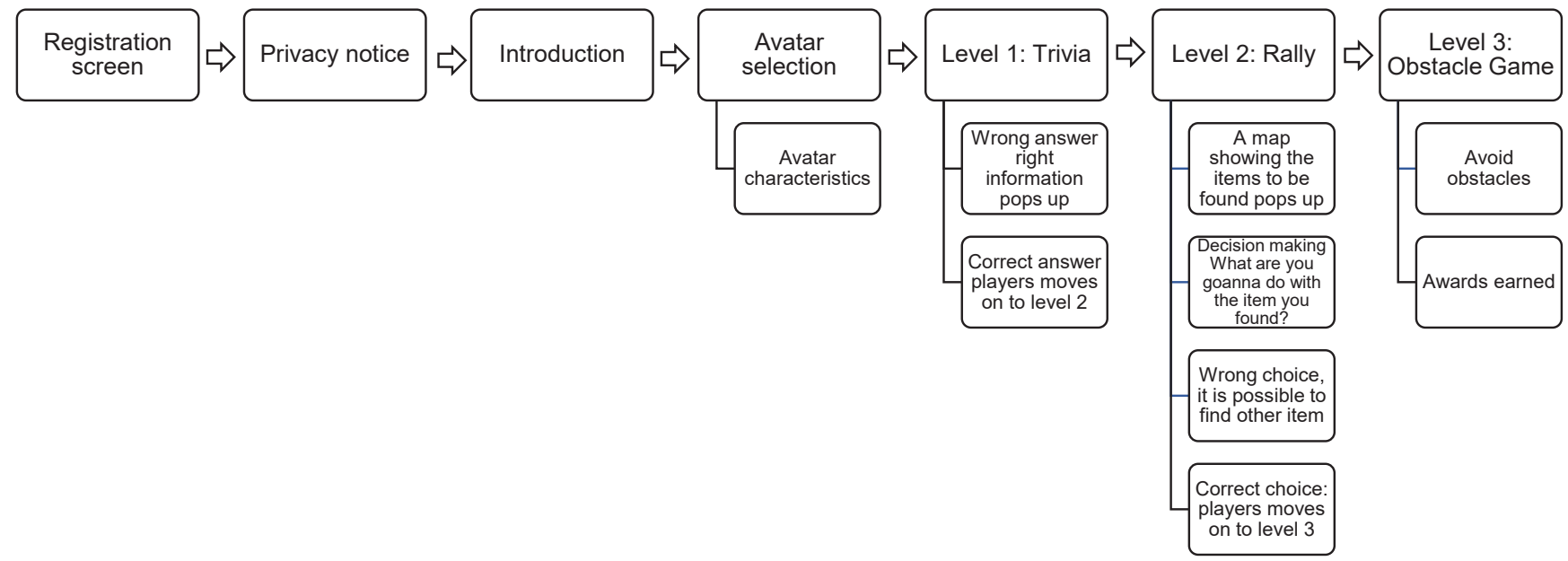

our app and provide instructions on how to play each of the three levels.

In the next screen, the player will choose the gender of the avatar. The player will interact with this avatar throughout the entire game and be able to customize her or him according to personal taste by selecting clothes, shoes, and style.

The first level is trivia, answering questions about tobacco use, physical and social damage, as well as the benefits of not smoking. If the player answers questions correctly, then the player can move on to the next level, but if the player does not, then the app will provide pieces of information such as short videos, infographics, pictures and memes, which will dispel doubts about the correct answer. The level will aim to inform participants, based on scientific evidence, about tobacco use to prevent classmates and family members from inducing them to smoke by giving them false information.

The second level is a rally that will be designed 
using augmented reality. The player will travel around the city he or she is living in when accessing our app to find two graphical elements: smokers and cigarette butts, which will be collected by clicking on. Then, on the screen the adolescent will see a question about what to do with that element. The player will have to choose wisely to move on to the next level.

The more elements caught by the player, the more points the player gets. This level aims to develop abilities for searching and recreation so that adolescents can perceive themselves as skillful and useful people who are able to make the best decisions on their health.

The third level is an obstacle game where the player using his or her avatar has to dodge cigarettes, while collecting water balloons to throw at smokers. It is a time-trial level whose objective is to reinforce in adolescents that smoking is harmful and they must avoid cigarette smoke.

Once players beat the three levels correctly and satisfactorily, they receive rewards consisting of discounts at movie theaters, clothing stores, bookstores, music stores, and entertainment as well as accessories for their avatars.

\section{DISCUSSION}

Our research was based on the BUS methodology, whereby three focus groups were held. We used UserCentered Design and Behavior Change Theories, resulting in the prototype for the 'No le entres' (don't jump in) mobile application, which aims to prevent smoking among adolescents. It is innovative in that we found no evidence of mobile applications being developed to prevent smoking among the Latino adolescent population.

In the participants' discourse, the Health Belief Model predominated, since they recognized the effects of smoking as a very serious issue. However, smoking is still a source of satisfaction for them. Thus, it is necessary for people not only to determine the risks of smoking, but also the benefits of not using tobacco ${ }^{10}$. We also used this model to design our app, since it considers that the player will receive prizes once all three levels of the game are beaten.

The Theory of Reasoned Action was another theory that was made visible in the participants' discourse, since participants frequently mentioned that friends usually induce them to smoke. However, if we replace a 'negative peer' with a peer with positive behavior, it will be easier to prevent young people from starting to smoke ${ }^{11}$. Considering this theory, we will include YouTubers and influencers to send positive messages.

Since participants mentioned that chatting with people, who have already gone through tobacco use disorder to determine the negative consequences, had positive effects ${ }^{12}$, we considered the Social Learning Theory to enhance the talent and ability of the user by asking him or her to make a correct decision.

When we explored mobile phone usage, the penetration of this device and the internet were both confirmed in different contexts. Although the three schools are located in towns with different levels of marginalization, the activities carried out by adolescents using this device did not differ. Therefore, at least for this population group, there are no technological gaps, since, regardless of whether they live in urban or rural areas, mobile phone usage is the same. This is consistent with Ferras et al. ${ }^{20}$ who claim that mobile phone usage seems to be resolving the lack of communication and isolation among adolescents living in rural contexts, which is also in line with what UNESCO stated in 2013, as regards the fact that an increasing number of people, including those from impoverished areas, own and use mobile devices ${ }^{21}$.

The results showed that adolescents spend around eight hours a day using their mobile phones. On weekends, usage increases, and this may be a problem. However, several authors recognize that, due to the time intended for this device, mobile phones can be used as a tool for adolescents to engage in healthy behaviors, especially prevention of drug use ${ }^{22-24}$.

Adolescents think that avatars they designed should be used to design our app and that the app should include chats to communicate with other young people. This is similar to the results obtained by Whittaker et al. ${ }^{13}$, since according to these authors an application is attractive for adolescents if there is music for relaxation, interaction with others, and exposure to 'real' and 'honest' role models with credible stories and animations.

Young people stated that informational videos 
should include information on how tobacco damages health. This is consistent with a study carried out in 2017 by Park et al..$^{25}$ who evaluated the effectiveness of videos made to prevent tobacco use.

Finally, adolescents feel more empathy and pleasure for game-type applications that provide them with features that encourage them to continue playing, such as abilities to improve avatar characteristics and to buy items on the internet. The same results were reported by Pope et al. ${ }^{18}$ who demonstrated that a game-type application needs to have rewards, competences, and accessibility to be attractive to young people.

The prototype design was based on a game with levels that help adolescents to stay active and enhance their skills. This game for health has been proven to help change user behavior ${ }^{26,27}$, and it can even influence one's values positively ${ }^{28}$.

The BUS methodology allowed adolescents, as the target population, to be involved in the application design since the beginning of the process, because, as has been demonstrated, for an application to be successful, the end user must be considered in the design. The sketch technique allowed adolescents to exercise their creativity and increase their confidence when expressing their ideas about the app, achieving completely user-centered results.

Few apps are aimed at preventing tobacco use ${ }^{8}$, including the Smokerface app. However, our 'No le entres' app is different, because in the initial conception Smokerface used the Mirroring ${ }^{29}$ approach, so end users were not involved. Most applications available on the market are aimed at treating $\mathrm{it}^{30}$.

Within the MPOWER plan to reverse the smoking epidemic, MPOWER stresses that adolescents who receive effective messages through television are less likely to become smokers. Such a plan was elaborated in 2008, a time when mobile phone use was not as popular as it is today. Thus, it is believed that using mobile phones to deliver these messages could be as effective as television ${ }^{31}$. Therefore, it is advisable for public health authorities to include in their traditional programs for adolescents to promote health, prevent diseases, and encourage the use of ICTs, since, as this study has shown, mobile phones are popular, and adolescents spend a substantial amount of time on them.

\section{Limitations}

Regarding limitations in this study, we mention that most participants were male, which possibly influenced the development of a war-type game. Another limitation was that we only applied the first two stages of the BUS model due to the resources available for the study. Therefore, it is important to continue to develop this app to evaluate its use and effect among adolescents; data on use frequency and the effectiveness of the theories of behavior change need to be obtained.

\section{CONCLUSIONS}

Guidelines for digital content design are provided to prevent tobacco consumption in the adolescent population. An important finding was that adolescents living in both urban and rural settings use mobile phones similarly. Thus, developing applications for this population group has a great potential to grow still further for m-Health strategies. Games for health can help modify user behavior and even positively influence their values. The final product was the prototype for the 'No le entres' (don't jump in) application.

\section{REFERENCES}

1. Instituto Nacional de Psiquiatría Ramón de la Fuente Muñiz, Instituto Nacional de Salud Pública, Comisión Nacional Contra las Adicciones, Secretaría de Salud. Encuesta Nacional de Consumo de Drogas, Alcohol y Tabaco 2016-2017: Reporte de Tabaco. ReynalesShigematsu LM. Zavala-Arciniega L, Paz-Ballesteros WC, Gutiérrez-Torres DS, et al, eds. México: INPRFM; 2017. https://gobqro.gob.mx/cecaqueretaro/wp-content/ uploads/2019/09/ENCODAT_TABACO_2016_2017.pdf. Accessed December 10, 2020.

2. Reynales-Shigematsu LM, Rodríguez-Bolaños R, OrtegaCeballos P, Flores Escartín MG, Lazcano-Ponce E, Hernández-Ávila M. Encuesta de Tabaquismo en Jóvenes. México: Instituto Nacional de Salud Pública; 2011. http:// spmediciones.mx/ebook/8529/free_download/. Accessed December 10, 2020.

3. del Pozo Irribarría J. La utilización de las nuevas tecnologías de comunicación e información para la adopción de comportamientos saludables: el consumo de drogas. In: del Pozo Irribarría J, Pérez Gómez L, Ferreras Oleffe M, eds. Adicciones y nuevas tecnologías de la información y de la comunicación. España: Gobierno de La Rioja; 2009:45-56. https://dialnet.unirioja.es/descarga/ libro/399981.pdf. Accessed December 10, 2020.

4. Malo-Cerrato S. The impact of mobile phones in the 
life of adolescents aged 12 - 16 years old. Comunicar. 2006;14(27):105-112. doi:10.3916/c27-2006-16

5. Vázquez-Cano E, Calvo-Gutiérrez E. Adolescentes y cibermedios. Una didáctica basada en aplicaciones periodísticas para smartphones. Estudios pedagógicos (Valdivia). 2015;41(2):255270. doi:10.4067/s0718-07052015000200015

6. Lee M, Lee H, Kim Y, et al. Mobile App-Based Health Promotion Programs: A Systematic Review of the Literature. Int J Environ Res Public Health. 2018;15(12):1-13. doi:10.3390/ijerph15122838

7. World Health Organization. WHO Framework Convention on Tobacco Control. https://apps.who.int/iris/bitstream/ handle/10665/42811/9241591013.pdf;jsessionid $=22$ B 962 C 8 E 70 B F A 97 C 83 B 5A 6 A EB 914066 ? sequence $=1$. Published 2003. Accessed September 19, 2019.

8. Sepúlveda-Cardona EA, Restrepo-Escobar SM. e-Salud y el estado de las Apps para adicciones: un análisis articulado de los cibermedios para ecosistemas digitales pensados a la Atención Primaria en Salud. Salud Drogas. 2018;18(2):185-194. doi:10.21134/haaj.v18i2.366

9. Patel S, Arya M. The BUS Framework: A comprehensive tool in creating an mHealth App utilizing Behavior Change Theories, User-Centered Design, and Social Marketing. J Mob Technol Med. 2017;6(1):39-45. doi:10.7309/jmtm.6.1.6

10. Janz NK, Becker MH. The Health Belief Model: a decade later. Health Educ Q. 1984;11(1):1-47. doi:10.1177/109019818401100101

11. Ajzen I, Madden TJ. Prediction of goal-directed behavior: Attitudes, intentions, and perceived behavioral control. J Exp Soc Psychol. 1986;22(5):453-474. doi:10.1016/0022-1031(86)90045-4

12. Bandura A. Social Cognitive Theory: An Agentic Perspective. Annu Rev Psychol. 1999;2(1):21-41. doi:10.1111/1467-839x.00024

13. Whittaker R, Maddison R, McRobbie H, et al. A multimedia mobile phone-based youth smoking cessation intervention: findings from content development and piloting studies. J Med Internet Res. 2008;10(5):e49. doi:10.2196/jmir.1007

14. Smith A, de Salas K, Schüz B, Ferguson SG, Lewis I. mHealth intervention design: creating mHealth interventions for behaviour change. Paper presented at: OzCHI '16: Proceedings of the 28th Australian Conference on Computer-Human Interaction; November 29, 2016; New York, NY: Association for Computing Machinery. doi:10.1145/3010915.3010986

15. Cafazzo JA, Casselman M, Hamming N, Katzman DK, Palmert MR. Design of an mHealth app for the self-management of adolescent type 1 diabetes: a pilot study. J Med Internet Res. 2012;14(3):e70. doi:10.2196/jmir.2058

16. Davis SR, Peters D, Calvo RA, Sawyer SM, Foster JM, Smith L. "Kiss myAsthma": Using a participatory design approach to develop a self-management app with young people with asthma. J Asthma. 2018;55(9):1018-1027. doi:10.1080/02770903.2017.1388391

17. Peters D, Davis S, Calvo RA, Sawyer SM, Smith L, Foster JM. Young People's Preferences for an Asthma SelfManagement App Highlight Psychological Needs: A Participatory Study. J Med Internet Res. 2017;19(4):e113. doi:10.2196/jmir.6994

18. Pope L, Garnett B, Dibble M. Engaging Adolescents to Inform the Development of a Mobile Gaming App to Incentivize Physical Activity. JMIR Res Protoc. 2017;6(8):e161. doi:10.2196/resprot.8113

19. Ulin PR, Robinson ET, Tolley EE. Investigación aplicada en salud pública: métodos cualitativos. Rev Inst Med Trop Sao Paulo. 2006;49(2):286. doi:10.1590/S0036-46652007000200015

20. Ferrás C, Pollán C, García Y, Pose M. La influencia del teléfono móvil en la conformación de la identidad de los adolescentes rurales. Estudio de caso en Galicia. Boletín de la Asociación de Geógrafos Españoles. 2012;60:297319. doi:10.21138/bage.1509

21. West M, Vosloo S. UNESCO policy guidelines for mobile learning. Kraut R, ed. Paris, France: UNESCO; 2013. https://unesdoc.unesco.org/ark:/48223/pf0000219641. Accessed December 10, 2020.

22. Gabelas-Barroso JA. Pantallas y jóvenes en el ágora del nuevo milenio. In: del Pozo Irribarría J, Pérez Gómez L, Ferreras Oleffe M, eds. Adicciones y nuevas tecnologías de la información y de la comunicación: perspectivas de su uso para la prevención y el tratamiento. Logrono, Spain: Gobierno de La Rioja; 2009:19-32. https:// dialnet.unirioja.es/descarga/libro/399981.pdf. Accessed December 10, 2020.

23. Funes Artiaga J. Móvil, messenger y otros aparatos para la vida. In: del Pozo Irribarría J, Pérez Gómez L, Ferreras Oleffe M, eds. Adicciones y nuevas tecnologías de la información y de la comunicación: perspectivas de su uso para la prevención y el tratamiento. Logrono, Spain: Gobierno de La Rioja; 2009:33-44. https:// dialnet.unirioja.es/descarga/libro/399981.pdf. Accessed December 10, 2020.

24. Osuna Expósito J. Prevención y Nuevas Tecnologías: una nueva forma de actuar. In: del Pozo Irribarría J, Pérez Gómez L, Ferreras Oleffe M, eds. Adicciones y nuevas tecnologías de la información y de la comunicación: perspectivas de su uso para la prevención y el tratamiento. Logrono, Spain: Gobierno de La Rioja; 2009:173-182. https://dialnet.unirioja.es/descarga/libro/399981.pdf. Accessed December 10, 2020.

25. Park E, Kulbok PA, Keim-Malpass J, Drake E, Kennedy MJ. Adolescent Smoking Prevention: Feasibility and Effect of Participatory Video Production. J Pediatr Nurs. 2017;36:197-204. doi:10.1016/j.pedn.2017.07.001

26. Khaled R, Barr P, Noble J, Fischer R, Biddle R. Fine Tuning the Persuasion in Persuasive Games. In: de 
Kort Y, IJsselsteijn W, Midden C, Eggen B, Fogg BJ, eds. Persuasive Technology. 2006;4744:36-47. doi:10.1007/978-3-540-77006-0_5

27. Lockton D, Harrison D, Stanton NA. The Design with Intent Method: a design tool for influencing user behaviour. Appl Ergon. 2010;41(3):382-392. doi:10.1016/j.apergo.2009.09.001

28. Barr P, Noble J, Biddle R. Video game values: Humancomputer interaction and games. Interact Comput. 2007;19(2):180-195. doi:10.1016/j.intcom.2006.08.008

29. Brinker TJ, Seeger W, Buslaff F. Photoaging Mobile Apps in School-Based Tobacco Prevention: The Mirroring Approach. J Med Internet Res. 2016;18(6):e183. doi:10.2196/jmir.6016

30. Abroms LC, Padmanabhan N, Thaweethai L, Phillips T. iPhone apps for smoking cessation: a content analysis. Am J Prev Med. 2011;40(3):279-285. doi:10.1016/j.amepre.2010.10.032

31. World Health Organization. WHO Report on the Global Tobacco Epidemic, 2008: The MPOWER package. https://apps.who.int/iris/bitstream/ handle/10665/43818/9789241596282_eng. pdf? sequence=1. Published 2008. Accessed October 3, 2019.

\section{ACKNOWLEDGMENTS}

We thank Miguel Alejandro Cámara Arciga for helping us design the prototype. We also thank the education authorities of the three schools and students who took part in the focus groups.

\section{CONFLICTS OF INTEREST}

The authors have completed and submitted the ICMJE Form for Disclosure of Potential Conflicts of Interest and none was reported.

FUNDING

This research received internal funding, in coordination with the Master's in Public Health of the University of Veracruz.

PROVENANCE AND PEER REVIEW

Not commissioned; externally peer reviewed. 